OPEN ACCESS

Edited by:

Mingqiang Li,

Sun Yat-sen University, China

Reviewed by:

Zhiqiang Yu,

Southern Medical University, China

Chao Zhao,

The University of Alabama,

United States

Jin Zhang,

Fuzhou University, China

${ }^{*}$ Correspondence:

Haotian Yuan

dentantony@163.com

Baihong Zheng

zhengbh@jlu.edu.cn;

hengbh@jlu.edu.cn

${ }^{\dagger}$ These authors have contributed equally to this work

Specialty section: This article was submitted to Biomaterials,

a section of the journal Frontiers in Bioengineering and

Biotechnology

Received: 22 April 2020

Accepted: 18 June 2020

Published: 17 July 2020

Citation:

Li H, Li Q, Li Y, Sang X, Yuan H and Zheng $B$ (2020) Stannic Oxide Nanoparticle Regulates Proliferation, Invasion, Apoptosis, and Oxidative

Stress of Oral Cancer Cells.

Front. Bioeng. Biotechnol. 8:768.

doi: 10.3389/fbioe.2020.00768

\section{Stannic Oxide Nanoparticle Regulates Proliferation, Invasion, Apoptosis, and Oxidative Stress of Oral Cancer Cells}

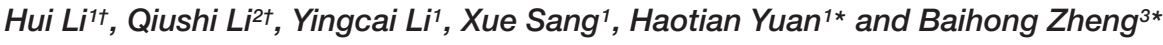 \\ ${ }^{1}$ Department of Stomatology, China-Japan Union Hospital, Jilin University, Changchun, China, ${ }^{2}$ VIP Integrated Department, \\ School and Hospital of Stomatology, Jilin University, Changchun, China, ${ }^{3}$ Department of Pediatrics, The Second Hospital \\ of Jilin University, Changchun, China
}

Objective: To explore the effects of $\mathrm{SnO}_{2}$ nanoparticles (NPs) on proliferation, invasion, apoptosis, and oxidative stress of oral cancer.

Methods: $\mathrm{SnO}_{2}$ NPs were prepared and characterized. Oral cancer cell lines CAL-27 and SCC-9 were cultured in vitro. We detected the effects of various concentrations of $\mathrm{SnO}_{2} \mathrm{NPs}(0,5,25,50,100,200 \mu \mathrm{g} / \mathrm{mL})$ on the proliferation of oral cancer cells, and observed the morphological changes, and measured the cells ability of migration, invasion and apoptosis condition, and the levels of oxidative stress were measured by detecting malondialdehyde (MDA) and reactive oxygen species (ROS). Besides, we also measured the changes of mRNA and protein levels of factors related to cell proliferation, migration, invasion, apoptosis, and oxidative stress.

Results: $\mathrm{SnO}_{2}$ NPs inhibited the proliferation of oral cancer cells in a concentrationdependent manner (all $P<0.05$ ). And $\mathrm{SnO}_{2} \mathrm{NPs}$ treatment could reduce the migration and invasion ability of cells (all $P<0.05$ ), induce apoptosis, and those effects were better when treated for $48 \mathrm{~h}$ than $24 \mathrm{~h}$ (all $P<0.05$ ). And $\mathrm{SnO}_{2} \mathrm{NPs}$ could induce oxidative stress in cells (all $P<0.05$ ). Besides, the concentrations of cyclin-D1, C-myc, matrix MMP-9, and MMP-2 in $\mathrm{SnO}_{2}$ NPs treated group was decreased (all $P<0.05$ ), and the expression levels of cleaved Caspase-3, cleaved Caspase-9, and Cytochrome C were increased (all $P<0.05$ ).

Conclusion: In the present study, we found that $\mathrm{SnO}_{2} \mathrm{NPs}$ could play a cytotoxic role in oral cancer cells, and inhibit cell proliferation, migration, and invasion, and induce oxidative stress and apoptosis, which suggests that $\mathrm{SnO}_{2} \mathrm{NPs}$ may have the effects of anti-oral cancer. However, a more in-depth study is needed to determine its roles.

Keywords: $\mathrm{SnO}_{2}$ nanoparticles, oral cancer, proliferation, invasion, apoptosis, oxidative stress

\section{INTRODUCTION}

Oral cancer is one of the most common human malignant tumors in the world (Shiga et al., 2011; Omori et al., 2020). Despite progress in cancer treatment, for patients with oral cancer, the 5-year survival rate is still less than $50 \%$ (Cristaldi et al., 2019). At present, the available treatments for oral cancer mainly include surgery, radiotherapy, and chemotherapy. After surgical treatment, it is 
easy to relapse, and the prognosis is poor. Although chemotherapy has effects to some extent, the tolerance and drug resistance of chemotherapy drugs are still severe problems faced by oral cancer patients. Therefore, it is necessary to find and develop a more effective and safer chemical molecular drug for treating the disease.

With the continuous development of nanomedicines, nanoparticles are now considered as a potential cancer treatment with bright future (Ding et al., 2019; Feng et al., 2019; Jiang et al., 2019; Li et al., 2019; Qi et al., 2019; Sun et al., 2019; Wang et al., 2019; Xu et al., 2019; Xiong et al., 2020; Yang et al., 2020). The nanoparticle is small and can facilitate the various biological reactions (Behzadi et al., 2017; Chen et al., 2017a). Tin oxide $\left(\mathrm{SnO}_{2}\right)$ is an essential n-type wide bandgap $(3.6 \mathrm{eV})$ semiconductor material. Currently, $\mathrm{SnO}_{2}$ nanoparticles are being used in different fields, including solar cells, gas sensors, catalysts, lithium-ion batteries, solid-state chemistry, etc. (Cheng et al., 2014). Increasingly, $\mathrm{SnO}_{2} \mathrm{NP}$ has more and more extensive use in the field of biomedicine, and studies have shown that $\mathrm{SnO}_{2}$ NP has antibacterial and antioxidant activity (Vidhu and Philip, 2015). For examples, in cell-related research, Tammina et al. (2017) observed that $\mathrm{SnO}_{2} \mathrm{NP}$ can exert anti-human colorectal cancer and anti-lung cancer effects through cytotoxicity; Roopan et al. (2015) reported the cytotoxic response of $\mathrm{SnO}_{2} \mathrm{NP}$ to hepatocellular carcinoma (Roopan et al., 2015); Ahamed et al. (2018) demonstrated that $\mathrm{SnO}_{2}$ NP could induce breast cancer cell toxicity through oxidative stress. In animal-related research, Yang et al. (2017) found that $\mathrm{SnO}_{2} \mathrm{NP}$ had an inhibitory effect on the weight gain of newborn rats. However, there is still little research on the mechanism of toxic effects of $\mathrm{SnO}_{2} \mathrm{NP}$ at the cellular and molecular levels. Therefore, before $\mathrm{SnO}_{2} \mathrm{NP}$ can be applied in the field of biomedicine, in-depth research on the possible biological roles of $\mathrm{SnO}_{2}$ is essential (Dong et al., 2012).

Since there is no relevant research on the role of $\mathrm{SnO}_{2} \mathrm{NP}$ in the initialization and progression of oral cancer, two oral cancer cells CAL-27 and SCC-9 were selected in this study to explore the possibility of $\mathrm{SnO}_{2} \mathrm{NP}$ in treating oral cancer by observing its effect on proliferation, invasion, apoptosis, and oxidative stress of the cells.

\section{MATERIALS AND METHODS}

\section{Synthesis of $\mathrm{SnO}_{2} \mathrm{NP}$}

$\mathrm{SnO}_{2} \mathrm{NP}$ was synthesized by the sol-gel method, see reference for details (Aziz et al., 2013). First, $5.0 \mathrm{~g}$ of $\mathrm{SnCl}_{4} \cdot 5 \mathrm{H}_{2} \mathrm{O}$ was dissolved in $200.0 \mathrm{~mL}$ of ethanol $\left(\mathrm{C}_{2} \mathrm{H}_{5} \mathrm{OH}\right)$ and stirred for $30 \mathrm{~min}$ by a magnetic stirrer. Then, $6.0 \mathrm{~mL}$ of acetylacetone was added to hydrolyze $\mathrm{SnO}_{2}$, and the solution was refluxed through an $80^{\circ} \mathrm{C}$ condenser. After that, the solution was further dried for $3 \mathrm{~h}$ in a $90^{\circ} \mathrm{C}$ hot air oven (Thermo Fisher Scientific, United States) to obtain $\mathrm{SnO}_{2}$ gel, which was then calcined at $400-500^{\circ} \mathrm{C}$ for $2 \mathrm{~h}$ to obtain $\mathrm{SnO}_{2} \mathrm{NP}$.

\section{Characterizations of $\mathrm{SnO}_{2}$ NP}

The absorption spectrum of $\mathrm{SnO}_{2} \mathrm{NP}$ was measured using a spectrometer (UV-1800, Shimadzu, Japan) at a resolution of
$0.5 \mathrm{~nm}$ and a wavelength range of 300-900 $\mathrm{nm}$. The structure of $\mathrm{SnO}_{2} \mathrm{NP}$ was analyzed by using $\mathrm{Ku}-\mathrm{C} \alpha$ ray powder $\mathrm{X}$-ray diffraction (XRD) with a wavelength of $1.54056 \AA$, and the XRD spectrum in the surrounding environment was recorded at a scan rate of $0.02^{\circ} / \mathrm{s}$ in the $2 \theta$ range of $20-80^{\circ}$. Besides, the characteristics of $\mathrm{SnO}_{2} \mathrm{NP}$ were observed with a transmission electron microscope (TEM).

\section{Cell Culture}

Human oral cancer cell lines CAL-27 and SCC-9 were purchased from ATCC (United States). The cells were incubated in DMEM medium containing $10 \%$ fetal bovine serum (Gibco, United States), $100 \mathrm{U} / \mathrm{mL}$ penicillin, and $100 \mu \mathrm{g} / \mathrm{mL}$ streptomycin (Invitrogen, United States), with 5\% carbon dioxide $\left(\mathrm{CO}_{2}\right)$ at $37^{\circ} \mathrm{C}$.

\section{Experimental Grouping and Treatment of Cells Exposed to $\mathrm{SnO}_{2}$ NP}

DMEM was used to prepare a $\mathrm{SnO}_{2} \mathrm{NP}$ storage solution (1.0 $\mathrm{mg} / \mathrm{mL}$ ), which was then diluted to an appropriate concentration (5-200 $\mu \mathrm{g} / \mathrm{mL}$ ). Before the experiment, $\mathrm{SnO}_{2} \mathrm{NP}$ of different concentrations was placed in the ultrasonic bath with $40 \mathrm{~W}$ for $15 \mathrm{~min}$ at room temperature, which could maintain nanoparticles being evenly distributed in DMEM and prevent aggregation. The cells were divided into the control group (DMEM group, $0 \mu \mathrm{g} / \mathrm{mL})$ and experimental groups $\left(\mathrm{SnO}_{2} \mathrm{NP}\right.$ concentration was $5,25,50,100$, and $200 \mu \mathrm{g} / \mathrm{mL}$ ), and two experimental treatment time points of 24 and $48 \mathrm{~h}$ were set.

\section{Detection of Cell Proliferation Behaviors}

Cell Counting Kit-8 (CCK-8, Donjindo, Japan) was used for the measurement. CAL-27 and SCC-9 cells were inoculated into 96well plates at a density of $1 \times 10^{4}$ cells/well. After 24 or $48 \mathrm{~h}$ of treatment for control and experimental groups, $10 \mu \mathrm{L}$ of CCK8 solution was added to each well for another $1 \mathrm{~h}$ of incubation at $37^{\circ} \mathrm{C}$. After that, the absorbance at $450 \mathrm{~nm}$ (Absorbance, A) was measured with a multifunctional microplate reader (Bio-Rad, Untied States). A blank well (only containing medium and CCK8 solution) was set in the experiment to counteract background interference. The formula for calculating cell proliferation activity is as follows (Chen et al., 2017b; Li et al., 2018):

$$
\begin{array}{r}
\text { Cell Viability }(\%)=\left(A_{\text {experimental group }}-A_{\text {blank group }}\right) / \\
\left(A_{\text {control group }}-A_{\text {blank group }}\right) \times 100 \% .
\end{array}
$$

Each group has four replicates.

\section{Cell Morphology Observation}

The morphological changes of cells in treatment groups were determined by a phase-contrast inverted microscope (Leica Microsystems Inc., United States).

\section{Cell Scratch Test}

First, cells were prepared for the control and experimental groups respectively, and then CAL-27 and SCC-9 cells were seeded on 6well plates at a density of $2 \times 10^{5}$ cell/well and cultured for $24 \mathrm{~h}$. 
Straight lines parallel to the cell layer were then drawn using a sterile pipette tip. After that, the control and experimental groups were treated accordingly, and the cells were photographed at 0 and $24 \mathrm{~h}$ with the use of a phase-contrast inverted microscope. Finally, ImageJ was used to measure the width of the scratch area and calculate the cell migration rate. The formula is as follows: cell migration rate $=($ scratch width at $0 \mathrm{~h}-$ scratch width at $24 \mathrm{~h}) / \mathrm{scratch}$ width at $0 \mathrm{~h} \times 100 \%$.

\section{Cell Invasion Experiment}

Transwell was used for the cell invasion test (Chen et al., $2017 b)$. First, cells were prepared for the control group and the experimental group. Then CAL-27 $\left(6 \times 10^{4}\right.$ cell/well $)$ and SCC9 cells $\left(8 \times 10^{4}\right.$ cell/well $)$ inoculated into $200 \mu \mathrm{L}$ of serum-free medium were plated in the upper chamber coated with Matrigel, and $500 \mu \mathrm{L}$ of medium containing $10 \%$ fetal calf serum was added in the lower chamber. The cells were incubated at $37^{\circ} \mathrm{C}$ for $24 \mathrm{~h}$, after which the cells on the membrane surface were fixed with $4 \%$ paraformaldehyde, stained with $0.1 \%$ crystal violet, and placed in a phase-contrast inverted microscope for cell counting.

\section{Detection of Oxidative Stress Indicators}

The oxidative stress was evaluated by determining the levels of malondialdehyde (MDA) and reactive oxygen species (ROS). According to the instructions, the MDA detection kit for lipid peroxidation (S0131, Biyuntian, China) and the active oxygen detection kit (S0033, Biyuntian, China) were used for detection, respectively.

\section{Western Blot to Detect Protein Expression}

The cells after the experimental treatment were washed with pre-cooled PBS and lysed with a strong RIPA lysis buffer (Biyuntian, China) containing protease inhibitors, which was subsequently centrifuged at $16,000 \mathrm{~g}$ at $4^{\circ} \mathrm{C}$ for $20 \mathrm{~min}$ to retain the supernatant. Then, the protein quantification was measured by the BCA protein concentration detection kit (Biyuntian, China). After that, the protein was denatured by heating at $98^{\circ} \mathrm{C}$ for $10 \mathrm{~min}$, and separated by SDS-PAGE gel electrophoresis. After electrophoresis, proteins on the gel were transferred to PVDF membrane (Millipore, United States), and the membrane was then blocked with a blocking solution (Biyuntian, China) for $1 \mathrm{~h}$ after the transfer. Subsequently, the membrane was incubated overnight at $4^{\circ} \mathrm{C}$ after the addition of the corresponding primary antibody. On the next day, the membrane was washed with TBST three times, and the secondary antibody conjugated with the corresponding horseradish peroxidase (HRP) was then incubated at room temperature for $2 \mathrm{~h}$. After that, the membrane was washed three times with TBST, and the Western blot was developed with ECL color developing solution (Biyuntian, China). Finally, the grayscale analysis was performed with Photoshop CS6. The primary antibodies used in this experiment were cleaved Caspase-3 (ab2302 17 kDa), Caspase-3 (ab13847 17 kDa), cleaved Caspase-9 (ab2324 46 kDa), Caspase-9 (ab202068 $46 \mathrm{kDa}$ ), matrix metalloproteinase 9 (Matrix metalloproteinase-9,
MMP-9) (ab38898 92 kDa), MMP-2 (ab97779 74 kDa), G1/Sspecific cyclin-D1 (Cyclin D1, CCND1) (ab134175 34 kDa), c-myc (Ab32072 $57 \mathrm{kDa}$ ), Cytochrome C (ab133504 $14 \mathrm{kDa})$, and $\beta$-actin (ab227387 $42 \mathrm{kDa}$ ), of which $\beta$-actin serves as an internal reference protein.

\section{Flow Cytometry to Detect Apoptosis}

The flow cytometer Annexin V-FITC/PI double staining method was used for the detection. CAL-27 and SCC-9 cells were seeded on 6 -well plates at a density of $2 \times 10^{5}$ cells/well. After treatment for 24 or $48 \mathrm{~h}$ in the control and experimental groups, cells were digested with trypsin digestion solution without EDTA and centrifuged at $1,000 \mathrm{rpm}$ for $5 \mathrm{~min}$ at room temperature to retain the cell pellet. Then, the cells washed with $1 \mathrm{~mL}$ of prechilled PBS were centrifuged at 3,000 rpm for $5 \mathrm{~min}$ at room temperature to retain the cell pellet, which was followed by PBS washing twice. After that, the cell pellet was added with $500 \mu \mathrm{L}$ of binding buffer to resuspend, $10 \mu \mathrm{L}$ PI and $5 \mu \mathrm{L}$ Annexin V-FITC were added, and cultured in the dark. After incubation, the apoptosis was immediately analyzed using flow cytometry (BD Biosciences, United States).

\section{Real-Time Fluorescence Quantitative PCR to Detect Expression Level of Target Genes}

The cells after the experimental treatment were washed with precooled PBS, and the total RNA was extracted from the cell line using TRIzol ${ }^{\circledR}$ reagent (Invitrogen, United States). After that, the concentration and purity of the RNA were measured with a multifunctional microplate reader. According to the instructions of the reverse transcription kit (Takara, Japan), $1 \mu \mathrm{g}$ of total RNA was used for PCR to obtain cDNA. Then, the SYBR Green kit (Takara, Japan) and target gene primers or internal reference gene $(\beta$-actin) primers were used to perform real-time fluorescence quantitative PCR (RT-qPCR). Finally, the expression cycle Ct value of each gene was measured, and the relative expression level was calculated according to this formula $2^{-\Delta \Delta C t}$. Primer sequences are shown in Table $\mathbf{1 .}$

\section{STATISTICAL ANALYSIS}

All experiments were independently repeated three times. The measurement data obtained in the experiment are expressed as mean \pm standard deviation, and software SPSS 18.0 was used for statistical analysis. Student's $t$-test was used for comparison

TABLE 1 | Primer sequence.

\begin{tabular}{lll}
\hline Gene & Forward $\left(\mathbf{5}^{\prime} \rightarrow \mathbf{3}^{\prime}\right)$ & Reverse $\left(\mathbf{5}^{\prime} \rightarrow \mathbf{3}^{\prime} \mathbf{)}\right.$ \\
\hline MMP-9 & CGCCAGTCCACCCTTGTG & CAGCTGCCTGTCGGTGAGA \\
MMP-2 & CGTCTGTCCCAGGATGACATC & ATGTCAGGAGAGGCCCCATA \\
CCND1 & GAACTACCTGGACCGCTTCC & TAGATGCACAGCTTCTCGGC \\
C-myc & AGCAAACCTCCTCACAGCCC & ACTGTCCAACTTGACCCTCT \\
Cytochrome C & CTITGGGCGGAAGACAGGTC & TTATTGGCGGCTGTGTAAGAG \\
$\beta$-actin & CATGTACGTTGCTATCCAGGC & CTCCTTAATGTCACGCACGAT
\end{tabular}



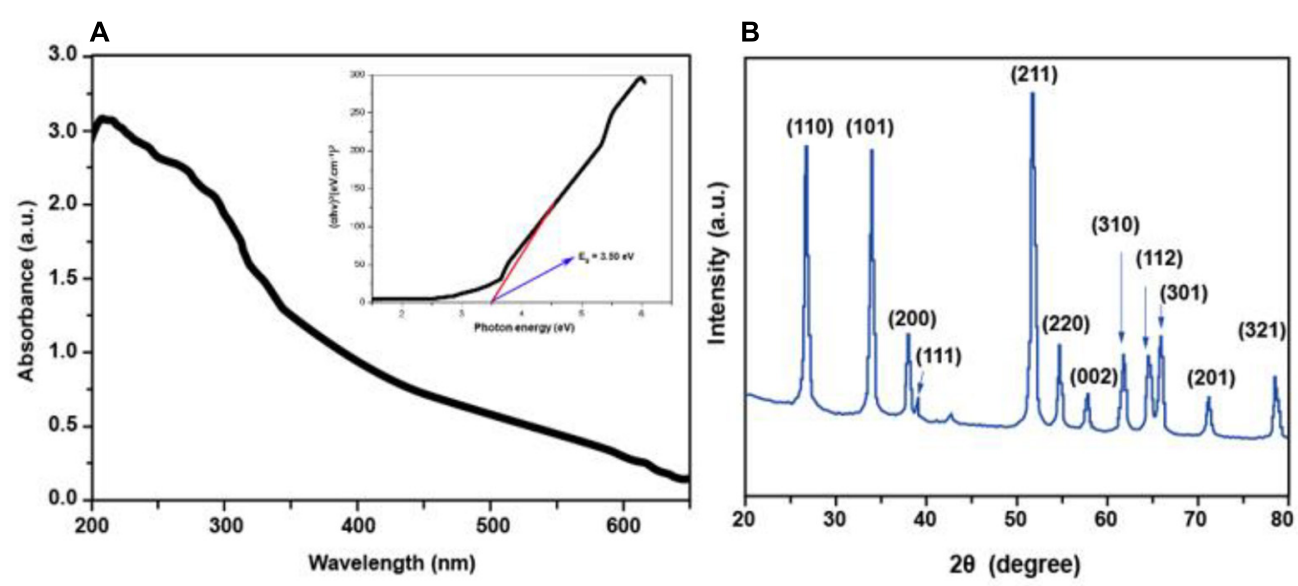

C

D
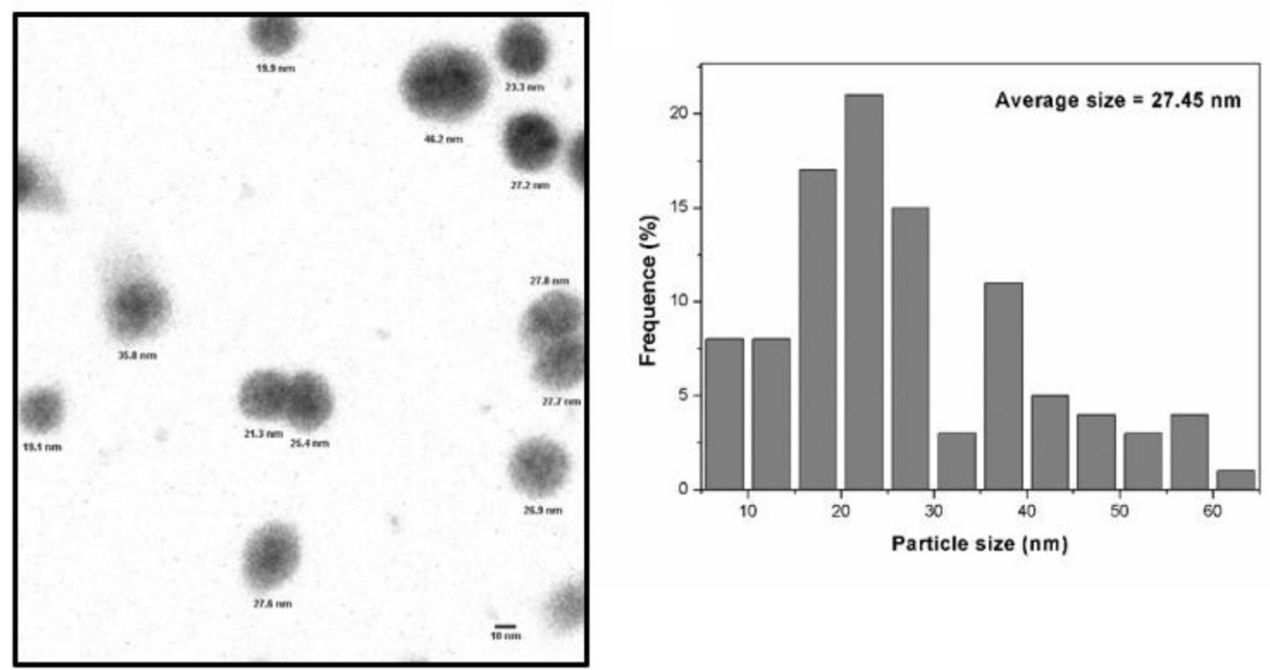

FIGURE 1 | Characterization of $\mathrm{SnO}_{2} \mathrm{NP}$. (A) Absorption spectra of $\mathrm{SnO}_{2} \mathrm{NP}$. Figure inset represents the bandgap energy of $\mathrm{SnO}_{2} \mathrm{NP}$. (B) XRD spectra of $\mathrm{SnO} \mathrm{O}_{2} \mathrm{NP}$. (C,D) TEM micrograph of $\mathrm{SnO}_{2} \mathrm{NP}$ and a histogram of the size distribution of $\mathrm{SnO}_{2} \mathrm{NP}$.

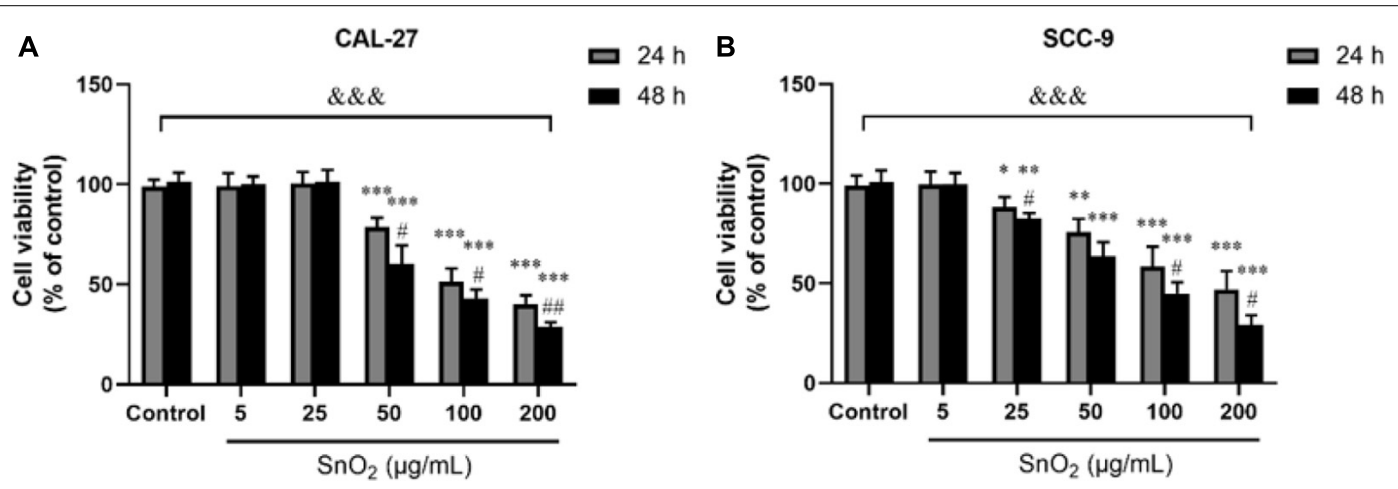

FIGURE 2 | $\mathrm{SnO}_{2}$ NP inhibited cell viability in oral cancer cells. (A,B) The viability of CAL-27 and SCC-9 cells was measured after treatment of different concentrations of $\mathrm{SnO}_{2} \mathrm{NP}$ at 24 or 48 h. $n=4$, compared with control group, ${ }^{\star} P<0.05$, ${ }^{\star \star} P<0.01$, ${ }^{\star \star \star} P<0.001$; compared with 24 h treated group, ${ }^{\#} P<0.05$, \#\# $P$ 0.01; compared in groups, ${ }^{\& \& \&} P<0.001$. 

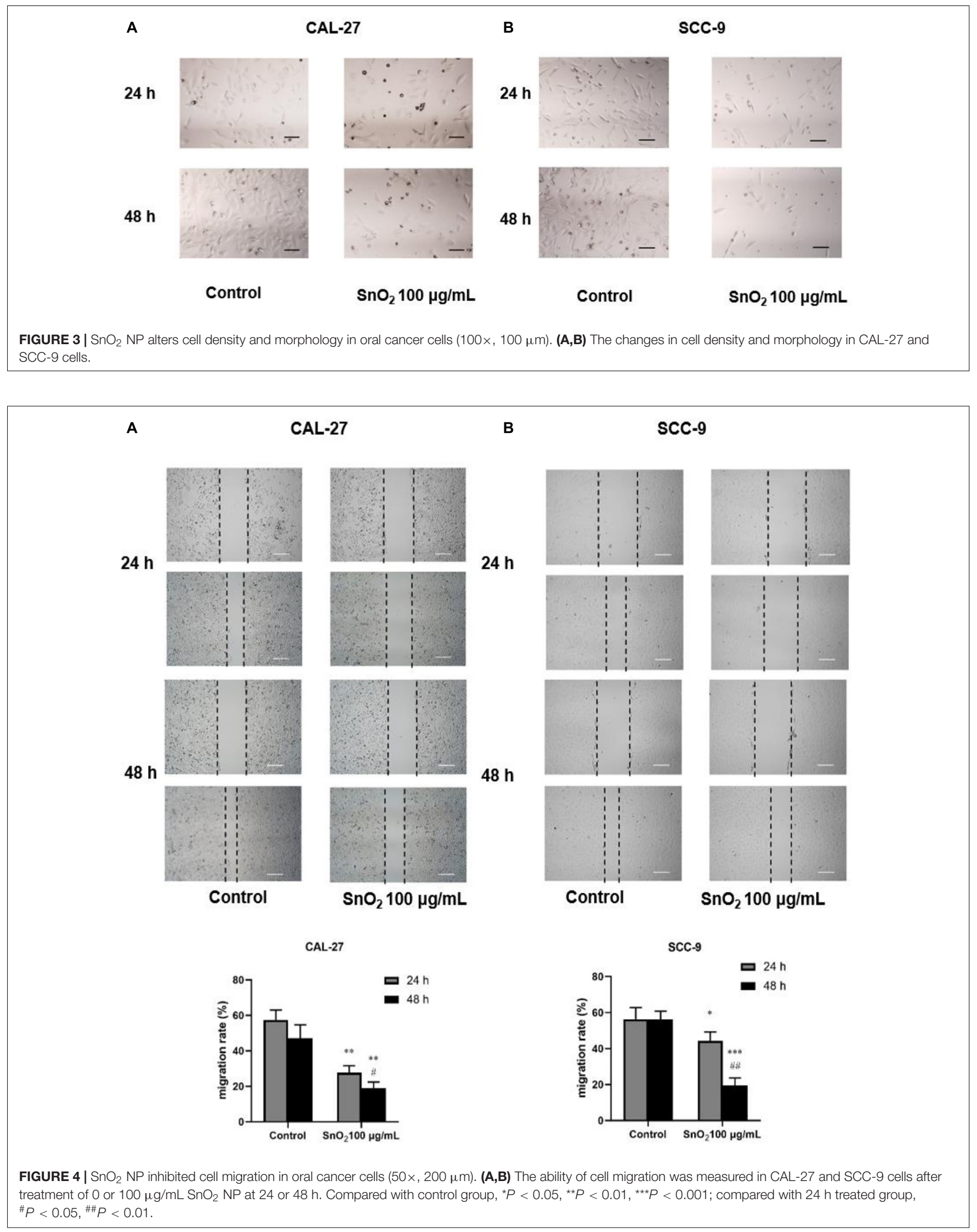
A

$24 \mathrm{~h}$

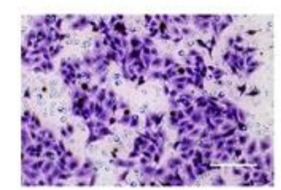

$48 \mathrm{~h}$

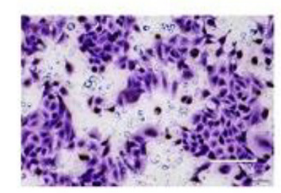

Control
CAL-27
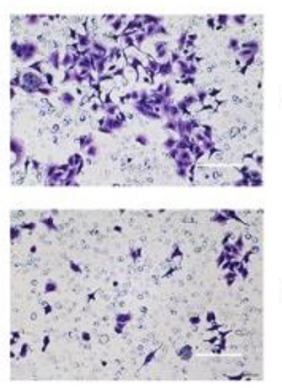

$\mathrm{SnO}_{2} 100 \mu \mathrm{g} / \mathrm{mL}$
B

$24 \mathrm{~h}$

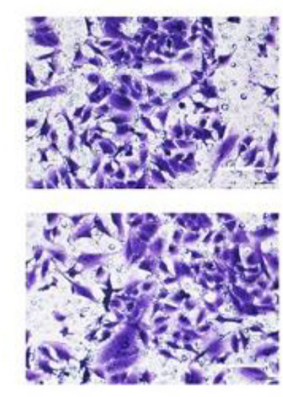

Control scc-9

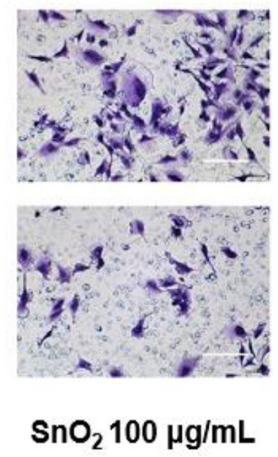

CAL-27
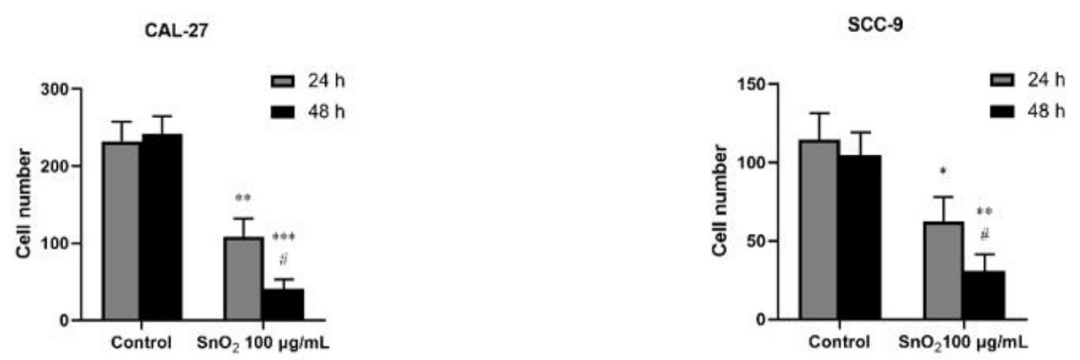

FIGURE 5 | SnO 2 NP inhibited cell invasion of oral cancer cells (100x, $100 \mu \mathrm{m})$. (A,B) The ability of cell invasion was measured in CAL-27 and SCC-9 cells after treatment of 0 or $100 \mu \mathrm{g} / \mathrm{mL} \mathrm{SnO} 2 \mathrm{NP}$ at 24 or $48 \mathrm{~h}$. Compared with control group, ${ }^{\star} P<0.05,{ }^{\star \star} P<0.01,{ }^{\star \star \star} P<0.001$; compared with $24 \mathrm{~h}$ treated group, $\# P<0.05$.

between the two groups, and one-way ANOVA was used for comparison within the group when considering the single factors. $P<0.05$ was considered statistically significant.

\section{RESULTS}

\section{Physicochemical Characterization of $\mathrm{SnO}_{2} \mathrm{NP}$}

As shown in Figure 1A, the absorption spectrum of $\mathrm{SnO}_{2}$ NP ranges from 200 to $700 \mathrm{~nm}$. The formula calculates the absorption coefficient $(\alpha)$ of $\mathrm{SnO}_{2} \mathrm{NP}: \alpha=\mathrm{A} / \mathrm{d}$ (A: absorbance, d: cuvette thickness) (Khan et al., 2014). According to the formula: $(\alpha h v)=A(h \nu-E g)$ (where $\mathrm{h} v$ is the photon energy, $\mathrm{A}$ is a constant that does not depend on the photon energy), the absorption coefficient $\alpha$ was used to make Tauc plots (Khan et al., 2017). The analysis found that the energy band gap of $\mathrm{SnO}_{2} \mathrm{NP}$ is $3.50 \mathrm{eV}$, which is consistent with other reports (Gattu et al., 2015; Mohanta et al., 2017). It is also known that the energy band gap of semiconductor NP plays a critical role in the toxicity of tumor cells (Rasmussen et al., 2010).

$\mathrm{X}$-ray diffraction analyzed the crystal structure of $\mathrm{SnO} 2 \mathrm{NP}$. As shown in Figure 1B, all peaks in XRD are related to the rutile structure of $\mathrm{SnO}_{2}$ (JCPDS No. 41-1445). According to the Scherrer equation: $d=K \lambda / \beta \operatorname{Cos} \theta$ (where $K=0.9$ is the shape factor, $\lambda$ is the X-ray wavelength of $\mathrm{Cu} \mathrm{K} \alpha$ rays (1.54 $\AA$ ), $\theta$ is the Bragg diffraction angle, and $\beta$ is the diffraction line at its maximum intensity (broadness) measured at half a radian), it is found that the average size of $\mathrm{SnO}_{2} \mathrm{NP}$ is about $13 \mathrm{~nm}$, and the XRD results are consistent with the results reported by other studies (Chen et al., 2014).

The appearance of $\mathrm{SnO}_{2} \mathrm{NP}$ was detected by TEM and shown in Figure 1C. The average TEM size of $\mathrm{SnO}_{2} \mathrm{NP}$ was calculated based on more than 300 nanoparticles and found that the average TEM size was $27.45 \pm 13.4 \mathrm{~nm}$ (Figure 1D).

\section{$\mathrm{SnO}_{2}$ NP Inhibit Proliferation of Oral Cancer Cells}

Figure 2A showed that compared with the control group, $\mathrm{SnO}_{2} \mathrm{NP}$ induced a significant decrease in the proliferation activity of CAL-27 cells in a concentration-dependent manner (50, 100, and $200 \mu \mathrm{g} / \mathrm{mL}$ ) (all $P<0.05$ ), and the inhibition effect was more significant at $48 \mathrm{~h}$ than that at $24 \mathrm{~h}$. When the concentration of $\mathrm{SnO}_{2} \mathrm{NP}$ was lower than $50 \mu \mathrm{g} / \mathrm{mL}(5$, $25 \mu \mathrm{g} / \mathrm{mL}$ ), there was no significant effect on cell proliferation activity (all $P>0.05$ ). Figure 2B showed that compared with the control group, $\mathrm{SnO}_{2} \mathrm{NP}$ induced a significant decrease in the proliferation activity of SCC-9 cells in a concentrationdependent manner $(25,50,100$, and $200 \mu \mathrm{g} / \mathrm{mL})$ (all $P<0.05)$, and the treatment at $48 \mathrm{~h}$ has stronger effects on cell proliferation activity than that at $24 \mathrm{~h}$. When the concentration of $\mathrm{SnO}_{2} \mathrm{NP}$ was less than $5 \mu \mathrm{g} / \mathrm{mL}$, there was no significant effect on cell proliferation activity $(P>0.05)$. Since $\mathrm{SnO}_{2}$ can exert toxicity on oral cancer cells when the concentration greater than 50 , 


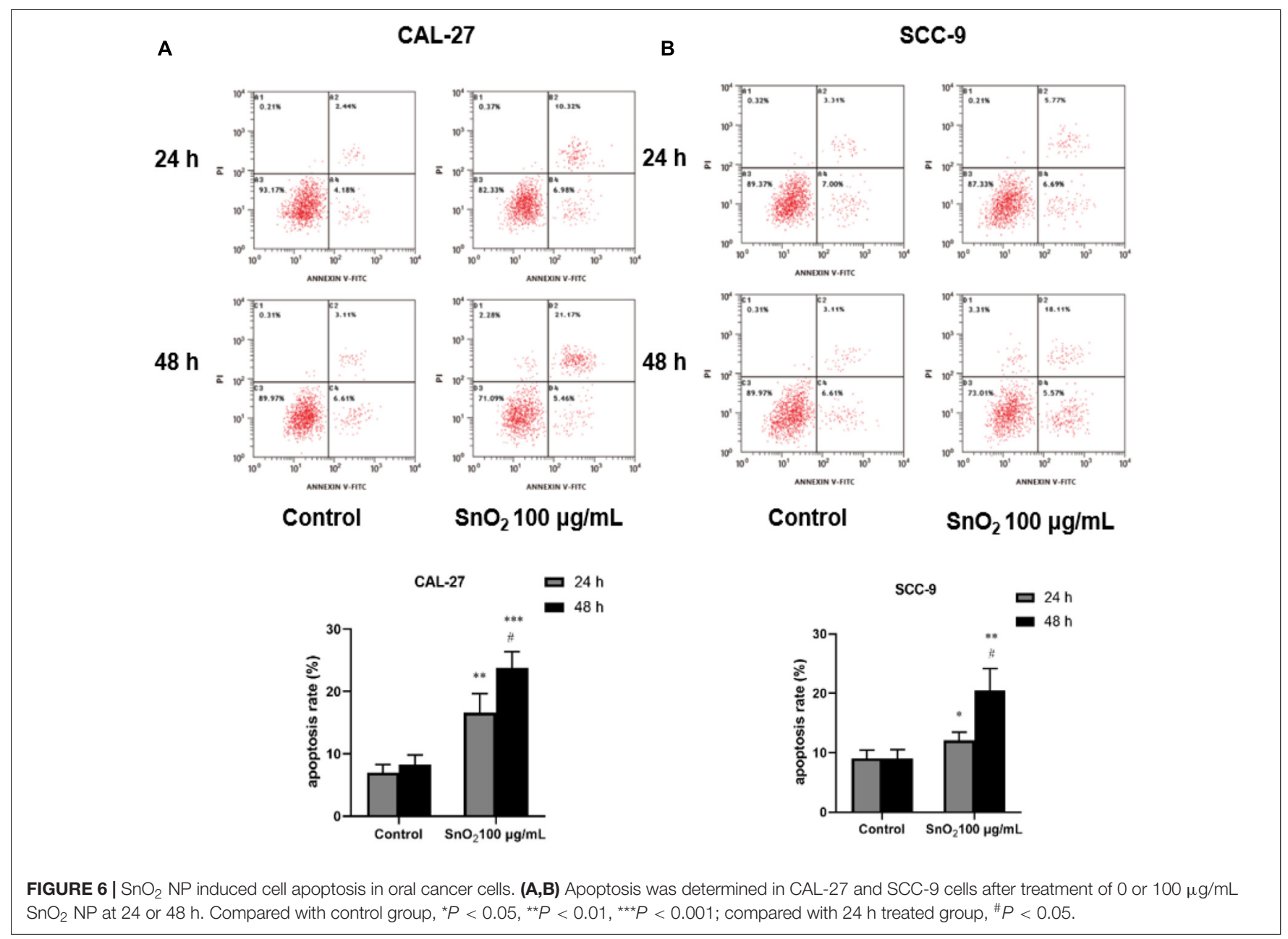

$100 \mu \mathrm{g} / \mathrm{mL}$ was used as the treatment concentration in the $\mathrm{SnO}_{2} \mathrm{NP}$ group.

\section{$\mathrm{SnO}_{2}$ NP Changed Density Morphology of Oral Cancer Cells}

Figure $3 \mathrm{~A}$ showed that compared with the control group, the treatment of $100 \mu \mathrm{g} / \mathrm{mL} \mathrm{SnO} \mathrm{SP}_{2} \mathrm{NP}$ can significantly reduce the CAL-27 cell density, and the cell density was changed more significantly with the treatment of $\mathrm{SnO}_{2} \mathrm{NP}$ at $48 \mathrm{~h}$ than that at $24 \mathrm{~h}$. As shown in Figure 3B, the changes caused by $\mathrm{SnO}_{2} \mathrm{NP}$ on SCC- 9 cells are consistent with the results from CAL-27 cells.

\section{$\mathrm{SnO}_{2}$ NP Inhibited Migration and Invasion of Oral Cancer Cells}

As shown in Figures 4A,B, compared with the control group, $\mathrm{SnO}_{2} \mathrm{NP}$ treatment significantly suppressed the migration of CAL-27 and SCC-9 cells (both $P<0.05$ ), and cells treated with $\mathrm{SnO}_{2} \mathrm{NP}$ for $48 \mathrm{~h}$ has a weaker migration ability than those treated for $24 \mathrm{~h}$ (all $P<0.05$ ).

As shown in Figures 5A,B, compared with the control group, $\mathrm{SnO}_{2} \mathrm{NP}$ treatment significantly reduced the invasive ability of CAL-27 and SCC-9 cells (both $P<0.05$ ), and the effect on cell invasion was more significant with the treatment of $\mathrm{SnO}_{2} \mathrm{NP}$ at $48 \mathrm{~h}$ than at $24 \mathrm{~h}(P<0.05)$.

\section{SnO2 NP Induced Apoptosis of Oral Cancer Cells}

Figure 6A indicated that compared with the control group, $100 \mu \mathrm{g} / \mathrm{mL} \mathrm{SnO}_{2} \mathrm{NP}$ can significantly induce apoptosis of CAL27 cells $(P<0.05)$, and the cells treated with $\mathrm{SnO}_{2} \mathrm{NP}$ at 48 h have more significant change than that at $24 \mathrm{~h}$. As shown in Figure 6B, the apoptosis induced by $\mathrm{SnO}_{2}$ NP on SCC- 9 cells was consistent with results with CAL-27 cells $(P<0.05)$.

\section{$\mathrm{SnO}_{2} \mathrm{NP}$ Induced Oxidative Stress in Oral Cancer Cells}

As shown in Figures 7A,C, CAL-27 cells treated with $100 \mu \mathrm{g} / \mathrm{mL} \mathrm{SnO} \mathrm{Sn}_{2} \mathrm{NP}$, compared with those of the control group, significantly increased the levels of oxidative stressrelated factors MDA and ROS (both $P<0.05$ ), and the cells treated with at $48 \mathrm{~h}$ changed more significant than at $24 \mathrm{~h}$. As shown in Figures $7 \mathbf{B}, \mathbf{D}$, the $\mathrm{SnO}_{2}$ NP-induced oxidative stress of SCC-9 cells was consistent with results from CAL-27 cells $(P<0.05)$. 

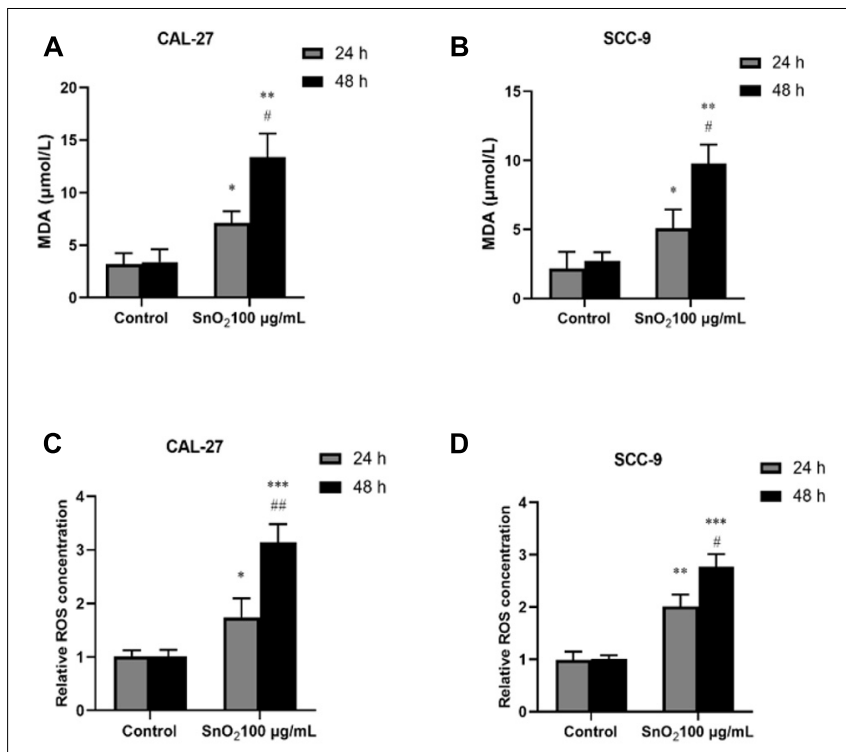

FIGURE 7 | $\mathrm{SnO}_{2} \mathrm{NP}$ induced cell apoptosis in oral cancer cells. (A,B) MDA levels were determined in CAL-27 and SCC-9 cells after treatment of 0 or $100 \mu \mathrm{g} / \mathrm{mL} \mathrm{SnO}_{2} \mathrm{NP}$ at 24 or $48 \mathrm{~h}$. (C,D) The effects of 0 or $100 \mu \mathrm{g} / \mathrm{mL}$ $\mathrm{SnO}_{2} \mathrm{NP}$ on ROS concentrations were tested in CAL-27 and SCC-9 cells at 24 or 48 h. Compared with control group, ${ }^{\star} P<0.05$, ${ }^{\star *} P<0.01$,

${ }^{\star \star \star} P<0.001$; compared with $24 \mathrm{~h}$ treated group, ${ }^{\#} P<0.05,{ }^{\# \#} P<0.05$.

\section{$\mathrm{SnO}_{2}$ NP Altered mRNA and Protein Expression of Oral Cancer Cell Proliferation, Migration, Invasion, Apoptosis, and Oxidative Stress-Related Genes}

CAL-27 cells are more sensitive to $\mathrm{SnO}_{2} \mathrm{NP}$ stimulation in terms of migration, invasion, and apoptosis, and were selected in the study for the Western blot and RT-qPCR experiments.

As shown in Figures 8A,B, compared with the control group, $100 \mu \mathrm{g} / \mathrm{mL} \mathrm{SnO} \mathrm{SP}_{2} \mathrm{NP}$ treatment at both 24 and $48 \mathrm{~h}$ could not only significantly inhibit the expression of proliferation-related factors CCND1 and c-myc in CAL-27 cells to varying degrees, but also decrease the mRNA levels of migration and invasion related factors MMP-2 and MMP-9 (both $P<0.05$ ), to promote the mRNA expression of oxidative stress-related factors Cytochrome C (both $P<0.05$ ).

Moreover, as shown in Figures 8C,D, compared with the control group, $100 \mu \mathrm{g} / \mathrm{mL} \mathrm{SnO}_{2} \mathrm{NP}$ treatment at 24 and $48 \mathrm{~h}$ can not only significantly inhibit the expression of proliferationrelated factors CCND1, c-myc in CAL-27 cells, but also decrease the protein levels of migration and invasion related factors MMP2 and MMP-9 (both $P<0.05$ ), promote the expression of such apoptosis-related proteins as cleaved Caspase-3, cleaved Caspase9 and oxidative stress-related factor Cytochrome $\mathrm{C}($ all $P<0.05)$.

\section{DISCUSSION}

$\mathrm{SnO}_{2}$ is a multifunctional metal oxide. Since $\mathrm{SnO}_{2} \mathrm{NP}$ can be used as antibacterial agents, disinfectants, and other products with excellent performance, $\mathrm{SnO}_{2} \mathrm{NP}$ has been gradually applied in the medical field. Recently, the critical role of $\mathrm{SnO}_{2} \mathrm{NP}$ in cancer treatment has attracted widespread attention. Some studies have confirmed that $\mathrm{SnO}_{2} \mathrm{NP}$ had a robust anticancer effect on specific cancer cells. For instance, $\mathrm{SnO}_{2} \mathrm{NP}$ could induce human HCT116 and A549 cells to produce ROS in vitro, which leads to cell death (Tammina et al., 2017); besides, it is found that $\mathrm{SnO}_{2} \mathrm{NP}$ treatment can cause HepG2 cells to occur Morphological changes and cytotoxic effects (Roopan et al., 2015); it is also demonstrated that $\mathrm{SnO}_{2} \mathrm{NP}$ can induce oxidative stress in MCF-7 cells, prompting the cells to synthesize ROS, increasing $\mathrm{H}_{2} \mathrm{O}_{2}$ levels, triggering lipid peroxidation, reducing glutathione and antioxidant enzymes levels, and finally causing cell damage (Ahamed et al., 2018); Moreover, $\mathrm{Lv}$ found that $\mathrm{SnO}_{2}$ nanofibers can not only reduce the cell activity of hepatocellular carcinoma SMMC-7721 but also induce apoptosis. Western blot detection found that the expression of Caspase-3, the apoptosis-related protein, was increased (Lv et al., 2018).

In this study, $\mathrm{SnO}_{2} \mathrm{NP}$ was prepared by the sol-gel method. Spectral analysis, XRD analysis, and TEM observation confirmed that the $\mathrm{SnO}_{2} \mathrm{NP}$ that we produced were consistent with literature records and could be used for experiments. This study first found that $\mathrm{SnO}_{2} \mathrm{NP}$ had anti-proliferative effects on two different kinds of oral cancer cells. Specifically, $\mathrm{SnO}_{2}$ NP induced a decrease in the activity of oral cancer cells in a dose-dependent manner, which became more evident with longer exposure time. This result is consistent with previous studies on the effects of $\mathrm{SnO}_{2} \mathrm{NP}$ on other cancers (Roopan et al., 2015; Tammina et al., 2017). At the same time, the protein and mRNA expressions of CCND1 and c-myc, the cell proliferation-related genes, were also detected. Some studies have found that CCND1 can regulate the cell cycle by controlling the G1/S phase transition, and increased expression of CCND1 will lead to the occurrence of cancer (Musgrove et al., 2011). As a carcinogenic transcription factor, C-Myc recognizes E-box and its related sequences in the target gene promoter. The increase of C-Myc level significantly improves the tumor proliferation ability (Liu et al., 2015). The study indicated that $\mathrm{SnO}_{2} \mathrm{NP}$ could inhibit the expression of CCND1 and c-myc in oral cancer cells, thereby exerting an inhibitory effect on cell proliferation. Also, the morphological changes in oral cancer cells after being treated with $\mathrm{SnO}_{2} \mathrm{NP}$ were observed and found that the cells shrank significantly. The cell density decreased, which further demonstrated that $\mathrm{SnO}_{2} \mathrm{NP}$ could exert cytotoxicity on oral cancer cells.

It is known that the cytotoxicity induced by $\mathrm{SnO}_{2} \mathrm{NP}$ is involved in the generation of oxidative stress, and Ahamed et al. (2018) demonstrated that in breast cancer cells $\mathrm{SnO}_{2}$ NP induced a dose-dependent increase in the production of oxidative products. As we all know, the production and removal of ROS in a normal healthy body are in a dynamic balance. When harmful factors destroy this balance, the level of free radical scavenging enzymes in the body will increase the production of ROS. Besides, it may also trigger the cleavage of lipid peroxides to MDA, which plays a cytotoxic 


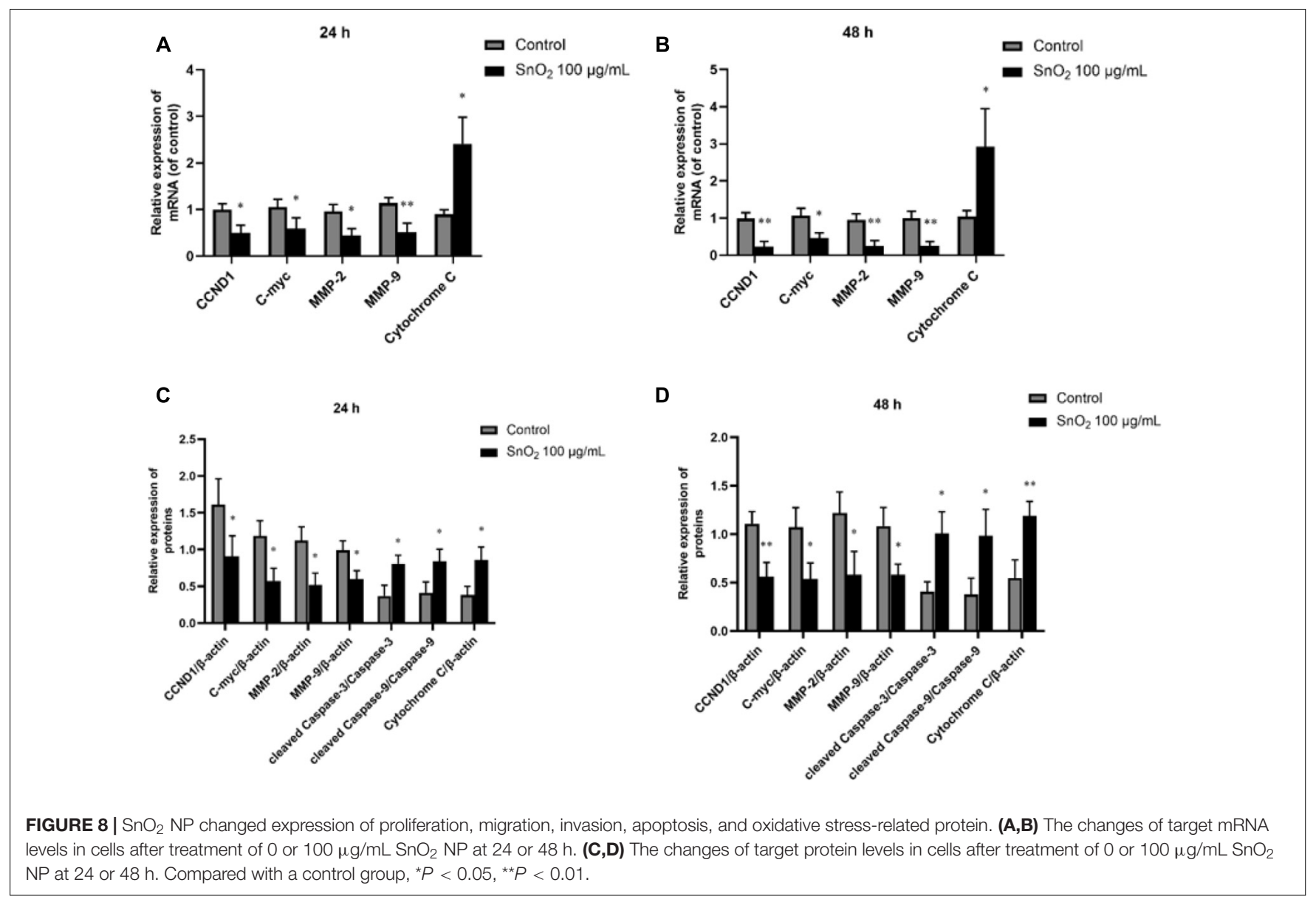

role (Kannan and Jain, 2000). Therefore, MDA and ROS are effective markers of the occurrence of oxidative stress in the body. This study found that SnO2 NPs increased MDA and ROS levels in CAL-27 and SCC-9 cells, and by detecting the expression of oxidative stress-related factors Cytochrome $\mathrm{C}$, it was found that $\mathrm{SnO} 2 \mathrm{NPs}$ can induce oral cancer cells to produce an increased amount of Cytochrome $\mathrm{C}$, thereby increasing oxidative stress. The above results indicated that $\mathrm{SnO}_{2} \mathrm{NP}$ could cause cell damage by inducing oxidative stress.

Cytochrome c plays a vital role in apoptosis in addition to its role in oxidative stress. It is known that caspase- 3 and caspase- 9 belong to the cysteine aspartic protease family and act as intermediary proteins in the degradation of proteolytic enzymes during apoptosis. In mammals, cytochrome $c$ together with apoptosis-activating factor 1 activates caspase 9, which subsequently leads to caspase- 3 activation, finally triggering a cascading waterfall effect and inducing apoptosis. This study found that $\mathrm{SnO} 2$ NPs can significantly increase the number of apoptosis of oral cancer cells, and the expression levels of apoptosis-related proteins Cleared Caspase- 3 and Cleared Caspase- 3 were also increased at different levels. These results suggest that $\mathrm{SnO}_{2} \mathrm{NP}$ can cause cell damage by inducing apoptosis.
In addition to apoptosis and oxidative stress, the effects of $\mathrm{SnO}_{2} \mathrm{NP}$ treatment on migration and invasion of oral cancer cells were also examined in this study. The results showed that oral cancer cells exposed to $\mathrm{SnO}_{2} \mathrm{NP}$ can significantly reduce their migration and invasion ability, and this inhibitory effect became more apparent, with the prolonged exposure time. In addition to visually observing changes in cell function, the mRNA and protein expression of migration and invasion related genes MMP-2 and MMP9 were also detected. MMPs are known to be essential for tumor angiogenesis and metastasis, and the destruction of the basement membrane by activating MMPs is a crucial step for cancer invasion and metastasis (Lin et al., 2014). Therefore, inhibition of MMPs expression can provide an initial target for preventing tumor metastasis. This study found that after treatment with $\mathrm{SnO}_{2} \mathrm{NP}$, both MMP-2 and MMP-9 protein and mRNA expressions in oral cancer cells were downregulated by varying degrees. This result is consistent with the results of migration and invasion experiments, suggesting that $\mathrm{SnO}_{2} \mathrm{NP}$ can inhibit the migration and invasion of oral cancer cells.

Despite the results shown in this study, because anti-tumor polymer nano-drugs are a new research hotspot and the research history is still relatively short, there are still a series of problems 
in this research, such as the lack of in-depth understanding of metabolic kinetics and biodistribution of the nano-drugs. For targeted tumor therapy, key factors (such as particle size, charge, surface chemistry) are still lacking in-depth exploration. Furthermore, due to the complexity of tumors, the therapeutic effect of nanomedicine in different tumor types and tumors with different stages of progressions may be different. Nevertheless, nanotechnology is still a very important hot subject that affects medicine. Although the research and development of nanotechnology-applied medicine are still only in its early stages, due to its rapid development, it will surely develop into a new discipline and new industry.

\section{CONCLUSION}

In summary, we found in this study that $\mathrm{SnO}_{2} \mathrm{NP}$ can exert cytotoxic effects on oral cancer cells by inhibiting cell proliferation, migration, and invasion abilities, and can also induce oxidative stress and apoptosis. Therefore, it is indicated that $\mathrm{SnO}_{2} \mathrm{NP}$ may have anti-oral cancer effects, which can provide a basis for future research and clinical application and has important theoretical value. However, more in-depth animal experiments and clinical trials are still needed to confirm its clinical value. This is a major limitation of this study and a direction for future research.

\section{REFERENCES}

Ahamed, M., Akhtar, M. J., Khan, M. M., and Alhadlaq, H. A. (2018). Oxidative stress mediated cytotoxicity of tin (IV) oxide ( $\mathrm{SnO} 2)$ nanoparticles in human breast cancer (MCF-7) cells. Coll. Surf. B Biointerf. 172, 152-160. doi: 10.1016/ j.colsurfb.2018.08.040

Aziz, M., Abbas, S. S., and Baharom, W. R. W. (2013). Size-controlled synthesis of SnO2 nanoparticles by sol-gel method. Mater. Lett. 91, 31-34. doi: 10.1016/j. matlet.2012.09.079

Behzadi, S., Serpooshan, V., Tao, W., Hamaly, M. A., Alkawareek, M. Y., Dreaden, E. C., et al. (2017). Cellular uptake of nanoparticles: journey inside the cell. Chem. Soc. Rev. 46, 4218-4244. doi: 10.1039/c6cs00636a

Chen, H., Wang, Q., Kou, C., Sui, Y., Zeng, Y., and Du, F. (2014). One-pot synthesis and improved sensing properties of hierarchical flowerlike $\mathrm{SnO} 2$ assembled from sheet and ultra-thin rod subunits. Sens. Actuat. B Chem. 194, 447-453. doi: $10.1016 /$ j.snb.2013.12.119

Chen, J., Ding, J., Wang, Y., Cheng, J., Ji, S., Zhuang, X., et al. (2017a). Sequentially responsive shell-stacked nanoparticles for deep penetration into solid tumors. Adv. Mater. 29:1701170. doi: 10.1002/adma.201701170

Chen, J., Ding, J., Xu, W., Sun, T., Xiao, H., Zhuang, X., et al. (2017b). Receptor and microenvironment dual-recognizable nanogel for targeted chemotherapy of highly metastatic malignancy. Nano Lett. 17, 4526-4533. doi: 10.1021/acs. nanolett.7b02129

Cheng, L., Ma, S., Wang, T., Li, X., Luo, J., Li, W., et al. (2014). Synthesis and characterization of $\mathrm{SnO} 2$ hollow nanofibers by electrospinning for ethanol sensing properties. Mater. Lett. 131, 23-26. doi: 10.1016/j.matlet.2014.05.151

Cristaldi, M., Mauceri, R., Di Fede, O., Giuliana, G., Campisi, G., and Panzarella, V. (2019). Salivary biomarkers for oral squamous cell carcinoma diagnosis and follow-up: current status and perspectives. Front. Physiol. 10:1476. doi: $10.3389 /$ fphys. 2019.01476

Ding, J., Chen, J., Gao, L., Jiang, Z., Zhang, Y., Li, M., et al. (2019). Engineered nanomedicines with enhanced tumor penetration. Nano Today 29:100800. doi: 10.1016/j.nantod.2019.100800

\section{DATA AVAILABILITY STATEMENT}

The original contributions presented in the study are included in the article/supplementary material, further inquiries can be directed to the corresponding author/s.

\section{ETHICS STATEMENT}

The animal study was reviewed and approved by the Animal Care and Use Committee at Jilin University.

\section{AUTHOR CONTRIBUTIONS}

HY and BZ proposed and designed the experiments. HL and QL carried out the experiments with the help of YL and XS. HL and QL drafted the manuscript and interpreted the data. HL, QL, HY, and $\mathrm{BZ}$ revised the manuscript. All authors contributed to the article and approved the submitted version.

\section{FUNDING}

The study was financially supported by the Science and Technology Development Program of Jilin Province (Grant No. 20200201519JC).

Dong, H., Lei, J., Ju, H., Zhi, F., Wang, H., Guo, W., et al. (2012). Target-cellspecific delivery, imaging, and detection of intracellular MicroRNA with a multifunctional SnO2 nanoprobe. Angew. Chem. Intern. Edn. 51, 4607-4612. doi: 10.1002/anie.201108302

Feng, X., Xu, W., Li, Z., Song, W., Ding, J., and Chen, X. (2019). Immunomodulatory nanosystems. Adv. Sci. 6:1900101. doi: 10.1002/advs. 201900101

Gattu, K. P., Ghule, K., Kashale, A. A., Patil, V., Phase, D., Mane, R., et al. (2015). Bio-green synthesis of Ni-doped tin oxide nanoparticles and its influence on gas sensing properties. RSC Adv. 5, 72849-72856. doi: 10.1039/c5ra13513c

Jiang, Z., Liu, Y., Feng, X., and Ding, J. (2019). Functional polypeptide nanogels. J. Funct. Poly. 32, 13-27.

Kannan, K., and Jain, S. K. (2000). Oxidative stress and apoptosis. Pathophysiology 7, 153-163.

Khan, M. M., Khan, W., Ahamed, M., and Alhazaa, A. N. (2017). Microstructural properties and enhanced photocatalytic performance of $\mathrm{Zn}$ doped $\mathrm{CeO} 2$ nanocrystals. Sci. Rep. 7, 1-11.

Khan, M. M., Kumar, S., Khan, M. N., Ahamed, M., and Al Dwayyan, A. (2014). Microstructure and blueshift in optical band gap of nanocrystalline AlxZn1xO thin films. J. Luminescen. 155, 275-281. doi: 10.1016/j.jlumin.2014.06.007

Li, S., Feng, X., Wang, J., Xu, W., Islam, M. A., Sun, T., et al. (2019). Multiantigenic nanoformulations activate anticancer immunity depending on size. Adv. Funct. Mater. 29:1903391. doi: 10.1002/adfm.201903391

Li, S., Zhang, T., Xu, W., Ding, J., Yin, F., Xu, J., et al. (2018). Sarcoma-targeting peptide-decorated polypeptide nanogel intracellularly delivers shikonin for upregulated osteosarcoma necroptosis and diminished pulmonary metastasis. Theranostics 8, 1361-1375. doi: 10.7150/thno.18299

Lin, C.-W., Chou, Y.-E., Chiou, H.-L., Chen, M.-K., Yang, W.-E., Hsieh, M.-J., et al. (2014). Pterostilbene suppresses oral cancer cell invasion by inhibiting MMP-2 expression. Expert Opin. Therap. Targ. 18, 1109-1120. doi: 10.1517/14728222. 2014.947962

Liu, Z., He, Q., Ding, X., Zhao, T., Zhao, L., and Wang, A. (2015). SOD2 is a C-myc target gene that promotes the migration and invasion of tongue squamous cell 
carcinoma involving cancer stem-like cells. Intern. J. Biochem. Cell Biol. 60, 139-146. doi: 10.1016/j.biocel.2014.12.022

Lv, H., Wu, C., Liu, X., Bai, A., Cao, Y., Shang, W., et al. (2018). Folatefunctionalized mesoporous hollow $\mathrm{SnO} 2$ nanofibers as a targeting drug carrier to improve the antitumor effect of paclitaxel for liver cancer therapy. Biomed Res. Intern. 2018:8526190.

Mohanta, D., Barman, K., Jasimuddin, S., and Ahmaruzzaman, M. (2017). MnO doped $\mathrm{SnO} 2$ nanocatalysts: activation of wide band gap semiconducting nanomaterials towards visible light induced photoelectrocatalytic water oxidation. J. Coll. Interf. Sci. 505, 756-762. doi: 10.1016/j.jcis.2017.06.064

Musgrove, E. A., Caldon, C. E., Barraclough, J., Stone, A., and Sutherland, R. L. (2011). Cyclin D as a therapeutic target in cancer. Nat. Rev. Cancer 11, 558-572. doi: $10.1038 / \mathrm{nrc} 3090$

Omori, H., Nishio, M., Masuda, M., Miyachi, Y., Ueda, F., Nakano, T., et al. (2020). YAP1 is a potent driver of the onset and progression of oral squamous cell carcinoma. Sci. Adv. 6:eaay3324. doi: 10.1126/sciadv.aay3324

Qi, B., Wang, C., Ding, J., and Tao, W. (2019). Editorial: applications of nanobiotechnology in pharmacology. Front. Pharmacol. 10:1451. doi: 10.3389/ fphar.2019.01451

Rasmussen, J. W., Martinez, E., Louka, P., and Wingett, D. G. (2010). Zinc oxide nanoparticles for selective destruction of tumor cells and potential for drug delivery applications. Expert Opin. Drug Deliv. 7, 1063-1077. doi: 10.1517/ 17425247.2010.502560

Roopan, S. M., Kumar, S. H. S., Madhumitha, G., and Suthindhiran, K. (2015). Biogenic-production of $\mathrm{SnO} 2$ nanoparticles and its cytotoxic effect against hepatocellular carcinoma cell line (HepG2). Appl. Biochem. Biotechnol. 175, 1567-1575. doi: 10.1007/s12010-014-1381-5

Shiga, K., Tateda, M., Katagiri, K., Nakanome, A., Ogawa, T., Asada, Y., et al. (2011). Distinct features of second primary malignancies in head and neck cancer patients in Japan. Tohoku J. Exper. Med. 225, 5-12. doi: 10.1620/tjem.225.5

Sun, Y., Ma, W., Yang, Y., He, M., Bai, L., Yu, Z., et al. (2019). Cancer nanotechnology: enhancing tumor cell response to chemotherapy for hepatocellular carcinoma therapy. Asian J. Pharm. Sci. 14, 581-594. doi: 10. 1016/j.ajps.2019.04.005
Tammina, S. K., Mandal, B. K., Ranjan, S., and Dasgupta, N. (2017). Cytotoxicity study of Piper nigrum seed mediated synthesized $\mathrm{SnO} 2$ nanoparticles towards colorectal (HCT116) and lung cancer (A549) cell lines. J. Photochem. Photobiol. B Biol. 166, 158-168. doi: 10.1016/j.jphotobiol.2016.11.017

Vidhu, V., and Philip, D. (2015). Biogenic synthesis of SnO2 nanoparticles: evaluation of antibacterial and antioxidant activities. Spectroch. Acta Part A Mol. Biomol. Spectrosc. 134, 372-379. doi: 10.1016/j.saa.2014.06.131

Wang, Q., Zhang, P., Li, Z., Feng, X., Lv, C., Zhang, H., et al. (2019). Evaluation of polymer nanoformulations in hepatoma therapy by established rodent models. Theranostics 9, 1426-1452. doi: 10.7150/thno.31683

Xiong, Q., Li, Y., Zhou, K., Chen, P., Guo, H., Chen, L., et al. (2020). Optimized fluorodendrimer-incorporated hybrid lipid-polymer nanoparticles for efficient siRNA delivery. Biomater. Sci. 8, 758-762. doi: 10.1039/c9bm01738k

Xu, J., Wang, H., Hu, Y., Zhang, Y. S., Wen, L., Yin, F., et al. (2019). Inhibition of CaMKII $\alpha$ activity enhances antitumor effect of fullerene C60 nanocrystals by suppression of autophagic degradation. Adv. Sci. 6:1801233. doi: 10.1002/advs. 201801233

Yang, C. X., Xing, L., Chang, X., Zhou, T. J., Yang, B., Jiang, H. L., et al. (2020). Synergistic platinum(II) prodrug nanoparticles for enhanced breast cancer therapy. Mol. Pharm. 17, 1300-1309. doi: 10.1021/acs.molpharmaceut.9b01318

Yang, J., Yang, K. Q., and Qiu, L. (2017). Biosynthesis of vitamin C stabilized tin oxide nanoparticles and their effect on body weight loss in neonatal rats. Environ. Toxicol. Pharmacol. 54, 48-52. doi: 10.1016/j.etap.2017.06.013

Conflict of Interest: The authors declare that the research was conducted in the absence of any commercial or financial relationships that could be construed as a potential conflict of interest.

Copyright (C) $2020 \mathrm{Li}, \mathrm{Li}$, Li, Sang, Yuan and Zheng. This is an open-access article distributed under the terms of the Creative Commons Attribution License (CC BY). The use, distribution or reproduction in other forums is permitted, provided the original author(s) and the copyright owner(s) are credited and that the original publication in this journal is cited, in accordance with accepted academic practice. No use, distribution or reproduction is permitted which does not comply with these terms. 